\title{
Introduction: navigating the frontiers of entrepreneurial university research
}

\section{Ulla Hytti}

The entrepreneurial university as a concept and phenomenon was introduced more than two decades ago (Etzkowitz, 1998; Clark, 1998) in a context where universities aimed at strengthening their impact in society (Jarvis, 2013; Siegel and Wright, 2015). Since then, research into this area has been burgeoning (Fayolle and Redford, 2014; Foss and Gibson, 2015), as has been the practical interest when many universities are establishing themselves as entrepreneurial universities (Liu, 2018). In his pioneering work, Clark (1998) came up with five different pathways for universities when transforming into entrepreneurial universities. As the first two pathways, he suggested that universities should both strengthen their steering core and diversify their funding base so that they would have the ability and autonomy to make decisions about their strategy and future directions independently. Third, he recommended extending their developmental periphery by establishing non-academic units, such as technology transfer offices or other centres, to make it easier for university stakeholders to get in contact and build relations with the university. Fourth, he emphasised the importance of the academic heartland - research and teaching - at the core of the entrepreneurial university. Finally, Clark suggested developing a university-wide entrepreneurial culture as a means for universities to operate in a flexible and entrepreneurial way. In essence, Clark understood an entrepreneurial university as not only contributing to entrepreneurship around it but as an institutional entrepreneur itself. Institutional entrepreneurship refers to the 'activities of actors who have an interest in particular institutional arrangements and who leverage resources to create new institutions or to transform existing ones' (Maguire, Hardy and Lawrence, 2004, p. 657), such as the university.

Thereafter, research on the entrepreneurial university has depicted the (ideal) models for the entrepreneurial university and its evolution - what the 
entrepreneurial university is and what it does when contrasted against other (historic) types of universities (Etzkowitz, 2013; 2014). The goal has been to understand the different types of entrepreneurial universities in terms of their entrepreneurial architecture (Foss and Gibson, 2015): their structures, systems, leadership, strategies and culture (see also Bronstein and Reihlen, 2014). Often, authors make sense of the changes in universities by investigating the environmental or institutional forces (or determinants) that explain or help to understand the transition towards the entrepreneurial university (Foss and Gibson, 2015) and the changes this proposes to the value proposition and value creation (Cunningham and Miller, $\mathrm{Ch} 7$, this volume).

However, technological advancements in digitalisation, robotisation, artificial intelligence and machine learning are transforming and disrupting societies, industries, businesses, governments, jobs, education and, to put it shortly, the way we live and experience our lives (e.g. Kile, 2013). Consequently, digitalisation may also contribute to transformations in the entrepreneurial university and its landscape, calling for new research in this area (Guerrero and Urbano, Ch 9, this volume; Salvador, Manzini, Urbinati, Puliga and Lazzarotti, Ch 13, this volume). University strategies on open data and open science (Hong and Walsh, 2009), as well as the more open and collaborative research processes, e.g. via citizen science (Follett and Strezov, 2015), create new layers to the entrepreneurial university and thus open up new research pathways. The deepening and diversifying collaboration with various stakeholders is giving birth to new roles and units within the university (thus similarly opening up the need to understand the dynamics within the university and in the relations with stakeholders (Warshaw, Ch 10, this volume; Creed, Heinonen and Zutshi, Ch 11, this volume)). As the processes of academic entrepreneurship and university-industry collaboration become more complex and many sided, generating knowledge of these processes is important (Aaboen, Dubois and Aarikka-Stenroos, Ch 12, this volume; Guerrero and Urbano, 2012).

The majority of prior research has focused on the societal and organisational levels as the units of analysis, and too little attention has been paid to what happens at the level of individuals and groups that actually work at universities. The organisational perspective could be enriched with individual-level analyses and benefit from an understanding of the activities and agency of university members, such as managers (Hytti, Eriksson, Montonen and Peura, 2020), faculty and students (Lahikainen, Peltonen, Hietanen and Oikkonen, Ch 8 , this volume), in contributing to and shaping the entrepreneurial university.

However, researchers adopting a less optimistic view on entrepreneurial university warn us that there is also a risk that the entrepreneurial university 
becomes a taken-for-granted kind of pervasive ideology (du Gay, 2000) that cannot be challenged or questioned. Rather than being understood as concrete activities implemented to support entrepreneurship at the university, the entrepreneurial university becomes a rhetorical move in the neoliberal discourse (Niska and Vesala, Ch 6, this volume). The entrepreneurial university 'establishes neoliberal ideals, redefines the values of European university education, and generates [an] instrumental and one-dimensional understanding of the purpose of university education' (Laalo, Kinnari and Silvennoinen, 2019 , p. 93). The entrepreneurial university could be seen as a vehicle to emphasise the new public management doctrine, meaning that universities should be more business-like and should focus on performance management and accountability, often accompanied by quantitatively measured financial and other targets (Jones et al., 2020). Thus, critical voices call for questioning the ideological underpinnings and pervasiveness of new managerialism or academic capitalism, as well as the notion of impact (for whom and how) (Deem, 2001; Mautner, 2005; Taylor, 2014).

Furthermore, research demonstrates how neoliberalism works by subjectifying the entrepreneurial self as something that we have voluntarily selected. It takes the shape of an ideal subject (Berglund, Hytti and Verduijn, 2020; Bröckling, 2015), i.e. to be a good academic is to be an entrepreneurial one. Despite the precariousness of their position, the entrepreneurial academic has internalised the goals to target and publish as much as possible in top journals and to seek and compete for research funding, for example. Hence, as we have believed that the effort to be entrepreneurial follows from our own desires (Fenwick, 2002), challenging and resisting it become difficult. Furthermore, the entrepreneurial university and related start-up events include a multisensory environment that intensifies the affectual sensation, contributing to our willingness to be a part of and identify with the entrepreneurial university by creating a sense of fun and excitement (Katila, Laine, and Parkkari, 2019; Katila, Kuismin, Laine and Valtonen, Ch 5, this volume).

In their editorial, Jones et al. (2020) wish to bring forth the opportunity for resistance for academics by opening up our own role and contribution to the performative university. By becoming aware and acknowledging our role, it opens up the possibility for agency. 'They (we?) keep on playing a role in audits, visitations, excellence exercises, funding schemes, and so on, activities which would grind to a halt, were academics to collectively refuse to play a role in them anymore' (Jones et al., 2020, p. 372). Obviously, the responsibility for resistance cannot be assigned to individuals; collective action is needed. Consequently, if we return to Clark (1998) and his ideas about the entrepreneurial university as an institutional entrepreneur with the aim of creating new 
institutions or transforming existing ones, it should be possible to envision a future of collective action in academia in order to engage in different acts, spaces, processes and mechanisms of resistance of the performative university and in coming up with alternatives (Jones et al., 2020) for the entrepreneurial university.

There is increasing awareness of global challenges, the so-called wicked problems, which the world and societies face today. Thus, the question is not only how universities are impactful in the areas they select but also how they enable global agendas to shape their own agenda. Solving societal challenges, climate change and sustainability and helping the world survive the global pandemic are giving rise to debates about 'societally responsible entrepreneurial universities' (Verduijn and Sabelis, Ch 3, this volume). Hence, the changes in and around universities transform how we think about entrepreneurial universities. The entrepreneurial university as an institutional entrepreneur gives prominence and a mandate, opportunity or even a responsibility to reflect on the challenges and changes society needs today - changes in which the entrepreneurial university can make a difference. Broadening the scope and understanding related to the entrepreneurial university opens up new opportunities for an 'alternative entrepreneurial university' (Berglund, Alexandersson, Jogmark and Tillmar, Ch 2, this volume), and the ability to envision different versions of the entrepreneurial university leaves more room for local and contextualised versions (Kaša, Elken and Paalzow, Ch 4, this volume). This also opens up the opportunity to break away from the narrow research commercialisation perspective. At the same time, we must be wary of promoting the entrepreneurial university (be it one directing research commercialisation, social change or other forms of alternative aims) as the only possible university form. Thus, when moving forward, we need to leave many doors open for 'academics and managers alike, to craft their institutions around a real social purpose' (Jones et al., 2020, p. 374).

The chapters in this book explore these subjects in forward-looking ways. Developing a closer link between the mainstream and critical perspectives allows us to bring in the axiological debate (Do we want to? Should we? How should we do it?) (Kyrö, 2015) to research on the entrepreneurial university and to be reflexive of how entrepreneurial universities are developed, by whom and for whom. When it comes to the individual chapters in this volume, I follow Czarniawska (2016) and abstain from summarising them. 'Readers need to familiarize themselves with the orginals, rather than relying on second-hand renditions. [...] All I can promise is that there is much to choose from' (Czarniawska, 2016, p. xiii). 


\section{Acknowledgement}

The author would like to acknowledge the financial support provided by the Academy of Finland (grant number 295960).

\section{References}

Berglund, K., Hytti, U. and Verduijn, K. (2020). 'Navigating the terrain of entrepreneurship education in neoliberal societies'. Entrepreneurship Education and Pedagogy, 2515127420935444.

Bröckling, U. (2015). The entrepreneurial self: Fabricating a new type of subject. Sage, London, Thousand Oaks CA, New Delhi and Singapore.

Bronstein, J. and Reihlen, M. (2014). 'Entrepreneurial university archetypes: A meta-synthesis of case study literature'. Industry and Higher Education, 28(4), 245-262.

Clark, B. R. (1998). Creating entrepreneurial universities: Organizational pathways of transformation. Issues in higher education. Elsevier Science Regional Sales, New York, NY.

Czarniawska, B. (Ed.). (2016). A research agenda for management and organization studies. Edward Elgar Publishing, Cheltenham, UK and Northampton, MA, USA.

Deem, R. (2001). 'Globalisation, new managerialism, academic capitalism and entrepreneurialism in universities: Is the local dimension still important?' Comparative Education, 37(1), 7-20.

Du Gay, P. (2000). 'Enterprise and its futures: A response to Fournier and Grey'. Organization, 7(1), 165-183.

Etzkowitz, H. (1998). 'The norms of entrepreneurial science: Cognitive effects of the new university-industry linkages'. Research Policy, 27(8), 823-833.

Etzkowitz, H. (2013). 'Anatomy of the entrepreneurial university'. Social Science Information, 52(3), 486-511.

Etzkowitz, H. (2014). 'The entrepreneurial university wave: From ivory tower to global economic engine'. Industry and Higher Education, 28(4), 223-232.

Fayolle, A. and Redford, D. T. (2014). Handbook on the entrepreneurial university. Edward Elgar Publishing, Cheltenham, UK and Northampton, MA, USA.

Fenwick, T. J. (2002). 'Transgressive desires: New enterprising selves in the new capitalism'. Work, Employment and Society, 16(4), 703-723.

Follett, R. and Strezov, V. (2015). 'An analysis of citizen science based research: Usage and publication patterns'. PloS one, 10(11), e0143687.

Foss, L. and Gibson, D. V. (Eds.). (2015). The entrepreneurial university: Context and institutional change. Routledge, London.

Guerrero, M. and Urbano, D. (2012). 'The development of an entrepreneurial university'. The Journal of Technology Transfer, 37(1), 43-74.

Hong, W. and Walsh, J. P. (2009). 'For money or glory? Commercialization, competition, and secrecy in the entrepreneurial university'. The Sociological Quarterly, 50(1), 145-171.

Hytti, U., Eriksson, P., Montonen, T. and Peura, K. (2020). 'Navigating enterprise at universities: A discursive analysis of academic managers' identity work', paper 
presented at the British Academy of Management, Conference in the Cloud (virtual conference), 2-4 September 2020.

Jarvis, P. (2013). Universities and corporate universities: The higher learning industry in global society. Routledge, London.

Jones, D. R., Visser, M., Stokes, P., Örtenblad, A., Deem, R., Rodgers, P. and Tarba, S. Y. (2020). 'The performative university: "Targets", "terror" and "taking back control" in academia'. Management Learning, 51(4), 363-377.

Katila, S., Laine, P. M. and Parkkari, P. (2019). 'Sociomateriality and affect in institutional work: Constructing the identity of start-up entrepreneurs'. Journal of Management Inquiry, 28(3), 381-394.

Kile, F. (2013). 'Artificial intelligence and society: A furtive transformation'. AI \& Society, 28(1), 107-115.

Kyrö, P. (2015). 'The conceptual contribution of education to research on entrepreneurship education'. Entrepreneurship \& Regional Development, 27(9-10), 599-618.

Laalo, H., Kinnari, H. and Silvennoinen, H. (2019). 'Setting new standards for homo academicus: Entrepreneurial university graduates on the EU agenda'. European Education, 51(2), 93-110.

Liu, W. (2018). Book Review. Lene Foss and David V. Gibson (eds.): The entrepreneurial university: context and institutional change, Routledge, London, 2015, 285pp, Higher Education, 75, 743-745.

Maguire, S., Hardy, C. and Lawrence, T. B. (2004). 'Institutional entrepreneurship in emerging fields: HIV/AIDS treatment advocacy in Canada'. Academy of Management Journal, 47(5), 657-679.

Mautner, G. (2005). 'The entrepreneurial university: A discursive profile of a higher education buzzword'. Critical Discourse Studies, 2(2), 95-120.

Siegel, D. S. and Wright, M. (2015). 'Academic entrepreneurship: Time for a rethink?'. British Journal of Management, 26(4), 582-595.

Taylor, Y. (Ed.). (2014). The entrepreneurial university: Engaging publics, intersecting impacts. Springer. 